\title{
Pemberdayaan Perpustakaan Desa melalui Implementasi Gerakan Nasional Gemar Membaca di Kecamatan Suwawa Kabupaten Bone Bolango
}

\author{
Sayama Malabar ${ }^{1}$, Salam $^{2}$, Jafar Lantowa ${ }^{3}$ \\ ${ }^{1,2,3}$ Fakultas Sastra dan Budaya, Universitas Negeri Gorontalo, Jl. Jend. Sudirman \\ No.6, Dulalowo Tim., Kota Tengah, Kota Gorontalo, Gorontalo 96128, Indonesia \\ email: sayamamalabar@gmail.com ${ }^{1}$, salamtolaki@ung.ac.id ${ }^{2}$, \\ Jafar.lantowa@ung.ac.id ${ }^{3}$
}

\begin{abstract}
Abstrak
Program Proyek di Desa - Kampus Merdeka ini bertujuan untuk pemberdayaan perpustakaan melalui implementasi gerakan nasional gemar membaca. Program ini dilaksanakan melalui metode pendidikan dan pelatihan, pendampingan, pelayanan dan pembinaan yang diharapkan akan berkelanjutan melalui kesadaran pihak terkait khususnya pemerintah dan pihak perpustakaan daerahdalam memperhatikan sarana dan prasarana perpustakaan desa yang memiliki potensi dalam mewujudkan program nasional gerakan membaca. Selain itu, untuk mendukung gerakan nasional gemar membaca, program juga diarahkan pada pembentukan komunitas literasi, pembuatan pondok literasi, dan taman bacaan rakyat Bone Bolango. Program KKN Merdeka Belajar-Kampus Merdeka dengan tema "Pemberdayaan Perpustakaan Desa Melalui Implementasi Gerakan Nasional Gemar Membaca" dilaksanakan dengan mengutamakan prinsip pemberdayaan masyarakat lokal dengan tujuan utama keberlanjutan program dan kesadaran masyarakat terhadap pentingnya literasi. Sehingga setelah Program KKN Merdeka Belajar-Kampus Merdeka selesai, masyarakat khususnya Karang Taruna dapat melanjutkan program yang telah dijalankan secara mandiri melalui wadah Komunitas Literasi Kecamatan. Desa perlu memberdayakan aset yang dimiliki baik dari sisi sumber daya manusia maupun pengelolaan sumber dana yang digunakan. Adapun fokus pemberdayaannya adalah peningkatan kualitas masyarakat di bidang keterampilan literasi dan sistem penyelenggaraan kelembagaan yang lebih baik dalam mendorong pengembangan program budaya baca. Dengan adanya budaya baca di desa, masyarakat akan memiliki kemampuan membaca sejak awal dan mendorong mereka untuk mencintaimembaca. Untuk mahasiswa KKN yang akan mengabdi di tahun-tahun berikutnya alangkah baiknya lebih meningkatkan komunikasi dengan masyarakat desa agar mempermudah menjalankan kegiatan-kegiatan yang dilaksanakan di desa Tinelo, Bubeya, dan Boludawa.
\end{abstract}

Kata Kunci: Pemberdayaan; Perpustakaan Desa; Gemar Membaca

\begin{abstract}
The Village Project Program -Independent Campus aims to empower libraries by implementing the national reading movement. This program is implemented through education and training, mentoring, service, and guidance, which are expected to be
\end{abstract}


sustainable through the awareness of related parties, especially the government and regional libraries. These parties are expected to pay attention to village library facilities and infrastructure that can realize the national reading movement program.Besides, to support the national reading movement, the program is also directed at forming literacy communities, literacy lodges, and reading parks in Bone Bolango.The Freedom to Learn - Independent Campus Community Service Program with the theme "Empowerment of Village Libraries through the Implementation of the National Reading Movement" is implemented by prioritizing the principle of empowering local communities with the primary objective of program sustainability and public awareness of the importance of literacy. Therefore, after the Freedomto Learn - Independent Campus Community Service Program is completed, the community, especially the Youth Organization, can continue the program that has been run independently through the Subdistrict Literacy Community forum. Villages need to empower their assets both in terms of human resources and management of the sources of funds used. The focus of empowerment is to improve the community's quality in the literacy skills sector and a better institutional administration system in encouraging the development of reading culture programs. Reading culture in the village can make people have the ability to read from the start and encourage them to love reading. It is recommended for students who take part in Community Service Program in the following years to further improve communication with the community in order to make it easier to run the programs implemented in Tinelo, Bubeya, and Boludawa villages.

Keywords: Empowerment; Village Library; Reading

(C) 2019 Sayama Malabar, Salam, Jafar Lantowa Under the license CC BY-SA 4.0 Correspondence author: Sayama Malabar, sayamamalabar@gmail.com, Gorontalo, Indonesia

\section{PENDAHULUAN}

Pembangunan karakter dimulai dari perubahan pemikiran yang benar, mendesain perilaku yang benar, pembiasaan perilaku yang istikomah, barulah karakter/budaya akan dipetik. Perubahan mindset merupakan pintu pembuka terjadinya perubahan yang lebih besar. Perubahan akan bermakna bila terdapat perbaikan praktik dan nilai tambah pada perilaku dan pembiasaan yang lebih positif. Saat ini, perubahan terpadu bidang tiga kemampuan dasar, yakni kemampuan membaca, menulis, dan berhitung (calistung) merupakan keniscayaan. Kualitas calistung anak negeri ini sungguh memprihatinkan dari tahun ke tahun. Menurut laporan "Programme for International Student 
Assesment" (PISA) tahun 2015, kemampuan literasi anak Indonesia berada pada urutan 64 dari 65 negara yang diasesmen. Fakta inimenginformasikan tentang perlunya revolusi mentalyang sungguhsungguhdari seluruh komponen bangsa untuk meningkatkan kualitas literasi melalui gerakan nasional sadar literasi (Samsuri, 2016: 147148). Gerakan nasional gemar membaca menjadi salah satu sarana dalam mewujudkan Indonesia melayani, bersih, tertib, dan bersatu. Melalui bahan bacaan, banyak informasi terkait dengan pesan karakter yang berpotensi mengubah pola pikir manusia Indonesia ke arah yang lebih baik demi memajukan dan mencerdaskan masyarakat Indonesia.

Kebutuhan literasi di era global ini menuntut pemerintah untuk menyediakan dan memfasilitasi sistem dan pelayanan pendidikan sesuai dengan UUD 1945, Pasal 31, Ayat 3, "Pemerintah mengusahakan dan menyelenggarakan satu sistem pendidikan nasional yang meningkatkan keimanan dan ketakwaan serta akhlak mulia dalam rangka mencerdaskan kehidupan bangsa, yang diatur dengan undang-undang." Ayat ini menegaskan bahwa program literasi juga mencakup upaya mengembangkan potensi kemanusiaan yang mencakup kecerdasan intelektual, emosi, bahasa, estetika, sosial, spiritual, dengan daya adaptasi terhadap perkembangan arus teknologi dan informasi. Upaya ini sejalan dengan falsafah pendidikan yang dinyatakan oleh Ki Hadjar Dewantara, bahwa pendidikan harus melibatkan semua komponen masyarakat (keluarga, pendidik profesional, pemerintah, dll.) dalam membina, menginspirasi/memberi contoh, memberi semangat, dan mendorong perkembangan anak.

Dalam mewujudkan program pemerintah terutama pihak perpustakaan nasional dalam mengimplementasikan gerakan gemar 
membaca, maka pemerintah menyediakan dan memfasilitasi layanan perpustakaan yang tersedia berbagai jenis buku untuk menjadi bahan bacaan masyarakat. Permasalahan rendahnya budaya literasi ini, tampak pada masyarakat di Kecamatan Suwawa khususnya di Desa Tinelo, Desa Bubeya, dan Desa Boludawa yang sebagian besar adalah pelajar yang memiliki akses pendidikan dasar sampai perguruan tinggi yang harusnya memiliki potensi dalam pengembangan pendidikan. Sebagaimana penuturan Kepala Desa Bubeya Bapak Rizaldi Usman, S.H., bahwa Bubeya memiliki potensi di bidang pendidikan, yakni tingginya jumlah pelajar pada masyarakat di desa tersebut, kepala desa Bubeya juga menuturkan bahwa di desa tersebut juga memiliki perpustakaan kecil yang telah disediakan dari pihak desa, yang jadi permasalahannya adalah kurangnya minat baca dan tulis para pelajar tersebut sehingga kurang memberikan kontribusi positif bagi pengembangan desa. Potensi pendidikan yang ada di Desa Bubeya perlu untuk digali dan dicarikan solusi berupa pemberdayaan dan pembelajaran bagi masyarakat dengan melibatkan sejumlah mahasiswa dalam menerapkan ilmu pengetahuan mereka kepada masyarakat. Selain itu, terdapat juga anak putus sekolah di Desa Tinelo, Bubeya, dan Boludawa dengan jumlah banyak, sehingga mereka perlu untuk diberdayakan dalam hal peningkatan pengetahuan dan keterampilan mereka dalam pembinaan karakter serta pengembangan desa.

Buku yang terdata berdasarkan survei sebelumnya oleh tim pelaksana tersedia sebanyak 907 buku yang terdiri atas berbagai bidang baik pendidikan, bahasa, sastra, kesehatan, pertanian, perikanan, perekonomian, sosial, budaya, agama, dan lain sebagainya. 
Namun, menurut pengelola perpustakaan di Desa, buku tersebut masih kurang menurut kebutuhan masyarakat sehingga kurangnya minat masyarakat dalam mengunjungi perpustakaan. Permasalahan juga ada padakurang minatnya sebagian masyarakat terutama pelajar yang ada di desa tersebut dalam memberdayakan perpustakaan sebagai tempat untuk meningkatkan pengetahuan. Setelah diwawancarai beberapa pelajar setempat, mereka berkomentar bahwa mereka lebih banyak memanfaatkan perpustakaan di sekolah daripada di perpustakaan desa karena kurangnya kebutuhan bahan bacaan mereka dan pelayanan pengelola perpustakaan yang kurang memperhatikan tingkat kebutuhan masyarakat terhadap jenis buku yang mereka inginkan. Hal tersebut karena, ketersediaan bahan bacaan yang kurang dan belum ada kegiatan inovasi yang dilaksanakan oleh aparat pemerintah desa dalam meningkatkan kegemaran membaca masyarakat sehingga pemberdayaan perpustakaan oleh masyarakat bisa terwujud.

Permasalahan tersebut harus menjadi perhatian utama yang membutuhkan solusi sehinggga harapan aparat pemerintah desa dalam mewujudkan program nasional gerakan membaca dapat terwujud. Oleh karena itu, melalui Proyek di Desa-Kampus Merdeka, pihak Dosen Universitas Negeri Gorontalo menawarkan sebuah kerja sama dengan mitra yakni Desa Tinelo, Desa Bubeya, dan Desa Boludawa Kecamatan Suwawa Kabupaten Bone Bolango Provinsi Gorontalo. Kegiatan pemberdayaan berupa penataan fasilitas perpustakaan melalui kebersihan dan kenyamanan perpustakaan, ketertiban pengelola, pengunjung dalam hal waktu pemanfaatan perpustakaan, dan pelayanan yang memadai dan menyenangkan oleh pihak pengelola 
perpustakaan serta yang paling utama adalah secara bergotong royong melibatkan partisipasi masyarakat untuk menambah koleksi bahan bacaan sesuai kebutuhan masyarakat.

Kegiatan Proyek di Desa-Kampus Merdeka ini dilaksanakan sebagai wujud pembelajaran di perguruan tinggi yang ototnom dan fleksibel sehingga tercipta kultur belajar yang inovatif, tidak mengekang, dan sesuai kebutuhan mahasiswa. Oleh karena itu, kegiatan proyek di desa ini mencakup KKN-T, PPL 2 (mengajar di sekolah secara virtual dari desa), dan riset/penelitian yang menghasilkan proposal skripsi berdasarkan permasalahan yang ditemukan mahasiswa selama di desa.

Permasalahan yang terdapat di Desa Tinelo, Desa Bubeya, dan Desa Boludawa Kecamatan Suwawa Kabupaten Bone Bolango Provinsi Gorontaloseperti yang diuraikan sebelumnya terdiri atas rendahnya minat baca tulis masyarakat yang tidak sesuai dengan amanat UU dalam mencerdaskan bangsa. Permasalahan lain juga tampak pada kurangnya apresiasi masyarakat terhadap sastra yang memiliki potensi dalam pembinaan karakter masyarakat khususnya pelajar. Oleh karena itu, kami memberi usulan penyelesaian masalah melalui pemberdayaan perpustakaan desa yang bertujuan untuk meningkatkan budaya literasi masyarakat melalui program proyek di desa oleh dosen dan mahasiswa Program Studi Pendidikan Bahasa dan Sastra Indonesia Fakultas Sastra dan Budaya Universitas Negeri Gorontalo. 


\section{METODE PELAKSANAAN}

Operasionalisasi Program Proyek di Desa (KKNT) terdiri atas 3 tahap yakni tahap persiapan dan perbekalan, tahap pelaksanaan dan rencana keberlanjutan program. Desa yang akan menjadi mitra pendampingan mahasiswa peserta KKNTematik yakni di Desa Tinelo, Desa Bubeya, dan Desa Boludawa Kecamatan Suwawa Kabupaten Bone Bolango Provinsi Gorontalo. Bentuk program yang akan dilaksanakan oleh peserta KKN-Tematik adalah program pendidikan dan pelatihan, desa oleh dosen pelaksana dan didampingi oleh mahasiswa peserta KKN-Tematik dengan mengundang narasumber dari kepala perpustakaan daerah dan kampus UNG.KKN ini dilaksanakan dengan mengutamakan prinsip pemberdayaan perpustakaan dengan tujuan utama keberlanjutan program dan kemandirian masyarakat terutama pengelola perpustakaan dan masyarakat di di Desa Tinelo, Desa Bubeya, dan Desa Boludawa Kecamatan Suwawa Kabupaten Bone Bolango Provinsi Gorontalo.

Volume pekerjaan dalam kegiatan Kuliah Kerja Sibermas (KKN)Tematik dinyatakan dalam bentuk jam kerja efektif mahasiswa (JKEM). Setiap mahasiswa harus melakukan pekerjaan sebanyak 144 JKEM per bulan selama minimal 2 bulan kegiatan KKNTematik, sehingga setiap mahasiswa harus melakukan pekerjaan sebanyak 288 JKEM dalam 2 bulan. Jumlah mahasiswa peserta kegiatan Kuliah Kerja Sibermas (KKN)- Tematik ini adalah 30 orang. Total volume jam kerja efektif mahasiswa (JKEM) adalah 10 mahasiswa $\times 288 \mathrm{JKEM}=2880$ jam kerja efektif mahasiswa (JKEM). 


\section{HASIL DAN PEMBAHASAN}

Hasil

Desa perlu memberdayakan aset yang dimiliki baik dari sisi sumber daya manusia maupun pengelolaan sumber dana yang digunakan. Adapun fokus pemberdayaan adalah peningkatan kualitas masyarakat di bidang keterampilan literasi dan sistem penyelenggaraan kelembagaan yang lebih baik dalam mendorong pengembangan program budaya baca. Dengan adanya budaya baca di desa, masyarakat akan memiliki kemampuan membaca sejak awal dan mendorong mereka untuk mencintaimembaca. Dengan demikian, kegiatan membaca akan menjadi aktivitas yang menyenangkan dan pada akhirnya menjadi kebiasaan pada masyarakat. Melaksanakan pendidikan dan pelatihan mengenai pengelolaan perpustakaan dan sosialisasi peningkatan minat baca masyarakat, Pendampingan pembenahan ruangan perpustakaan dengan melibatkan donatur dalam memperhatikan kelayakan ruangan perpustakaan desa dan membuat pondok literasi dan taman bacaan rakyat Bone Bolango hingga pembentukan komunitas literasi di desa.

Adapun uraian kerja dari program Pemberdayaan Perpustakaan Desa melalui Implementasi Gerakan Nasional Gemar Membaca di Kecamatan Suwawa Kabupaten Bone Bolango Provinsi Gorontalo ini adalah sebagai berikut:

Pendirian dan Pengembangan Pemberdayaan Perpustakaan Desa melalui Implementasi Gerakan Nasional Gemar Membaca di Kecamatan Suwawa Kabupaten Bone Bolango Provinsi Gorontalo

1. Observasi awal terkait minat baca masyarakat 
Program yang dilaksanakan mahasiswa diawali dengan observasi awal terkait dengan minat baca masyarakat Desa Bubeya, Boludawa, dan Tinelo. Kegiatan ini dilaksanakan pada hari sabtu. Minggu tanggal 5 s.d 6 September 2020. Dari hasil observasi ditemukan bahwa rendahnya minat baca pada masyarakat, karena sebagian warga bahkan jarang memiliki buku bacaan dan jarang mempergunakan waktu untuk sekadar membaca. Belum adanya fasilitas perpustakaan yang memadai di desa, belum tersedianya pondok literasi dan taman bacaan rakyat untuk memotivasi minat bacaan rakyat, dan kurangnya kesadaran pemerintah desa dan masyarakat dalam memberdayakan. Adapun observasi tersebut tampak pada gambar berikut.

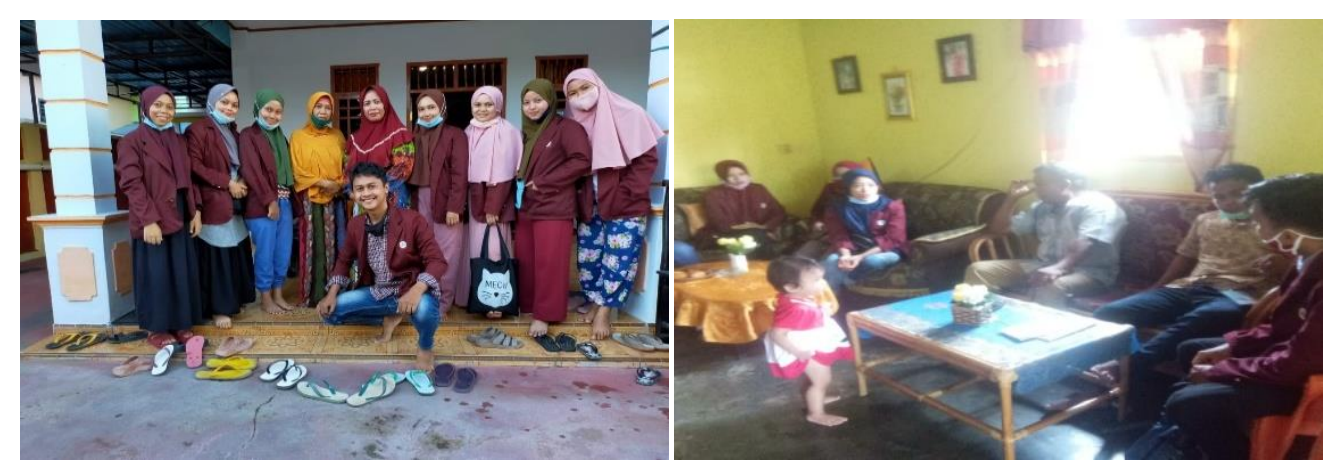

2. Observasi terkait perpustakaan desa

Sebagai kelanjutan dari program inti yang akan dilakukan yaitu pemberdayaan perpustakaan desa maka kegiatan selanjutnya yang dilakukan adalah peninjauan keadaan perpustakaan yang ada di desa. Baik di desa Bubeya, Boludawa, dan Tinelo. Dari hasil peninjauan ditemukan bahwa beberapa masalah terkait dengan perpustakaan desa. Diantaranya, adalah pengalih fungsian ruang perpustakaan di Desa Boludawa, dan parahnya tidak ada ruang perpustakaan di desa Tinelo dan Bubeya. Belum adanya pengelola yang terorganisir, dan 
minimnya buku yang tersedia di perpustakaan. Adapun observasi tersebut tampak pada gambar berikut:
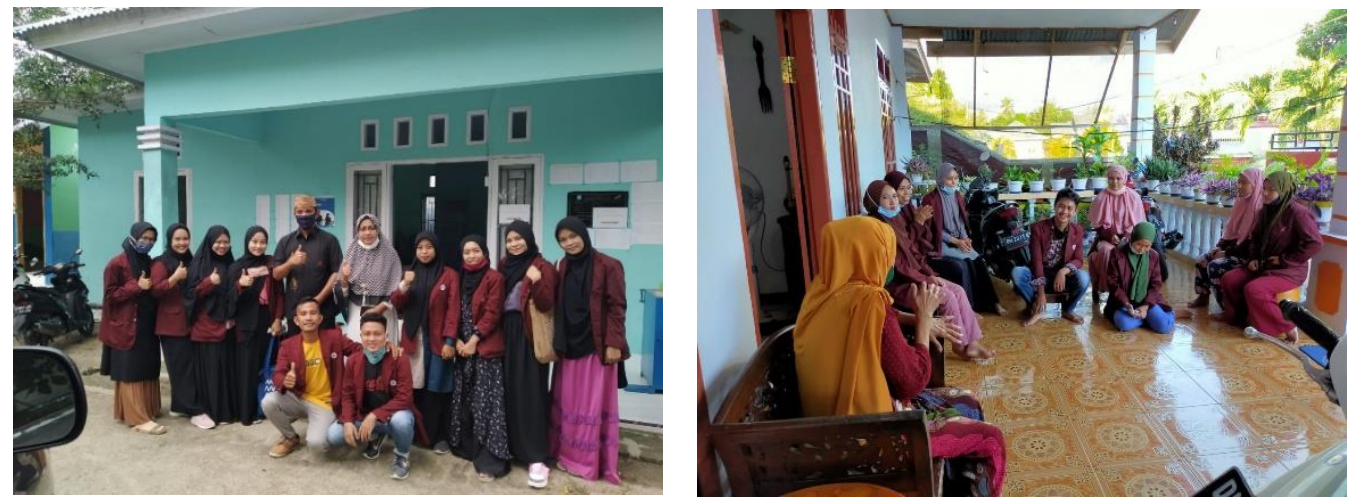

3. Pendataan buku-buku sebagai tahap awal perencaan ruang perpustakaan

Penataan ruang perpustakaan yang ada di desa Bubeya, Tinelo, dan Boludawa dilakukan dengan waktu yang cukup lama. Hal ini disebabkan oleh masalah yang ditemui terkait dengan gedung, sarana dan prasarana serta pengelola dari perpustakaan desa. sebagai usaha memberdayakan kembali perpustakaan desa Bubeya, Boludawa, dan Tinelo mulai membersihkan, mendata dan pemilahan buku-buku perpustakaan, serta penempelan dan label dan penulisan laporan data buku donasi untuk nantinya diserahkan ke pemerintah desa khususnya pengelola perpustakaan. 

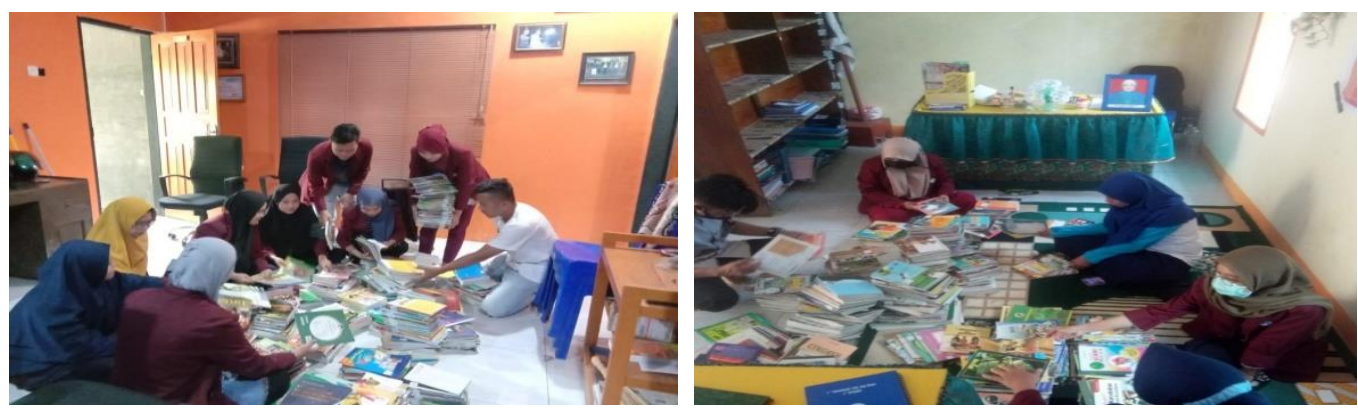

4. Pembuatan perpustakaan baru desa

Pembuatan perpustakaan desa kemudian mulai dilaksanakan, ruangan perpustakaan yang ada di desa Bubeya dan Tinelo tadinya dialih fungsikan kemudian ditata kembali dan diberdayakan, lain halnya dengan di Desa Boludawa dibuatnya peprustakaan baru bersama kepala desa Boludawa bekerja sama dengan karang taruna desa Boludawa sebagai usaha penataan kembali perpustakaan beserta sarananya.
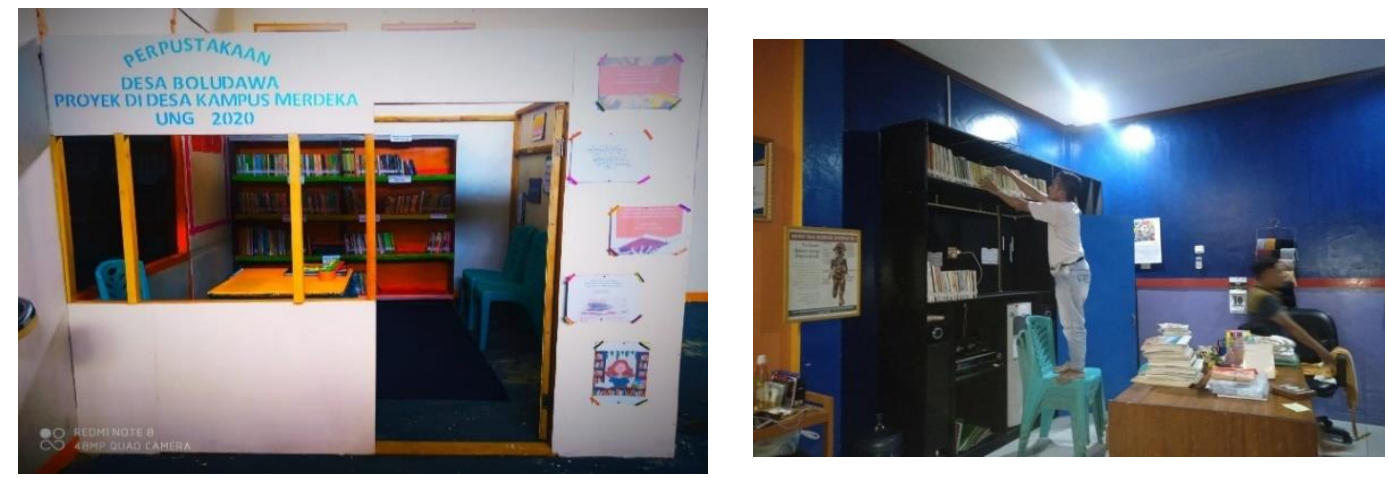

5. Pengadaan slogan yang bertemakan pentingnya membaca buku 
Mahasiswa KKN-MBKM melakukan kegiatan pengadaan papan slogan minat baca yang meliputi proses pembuatan dan pemasangan plakat sebagai usaha meningkatkan minat baca masyarakat desa. Slogan ini kemudian di pasang tempat yang mudah dilihat dan dibaca oleh masyarakat sekitar utamanya anak-anak yang sering bermain dilingkungan desa.
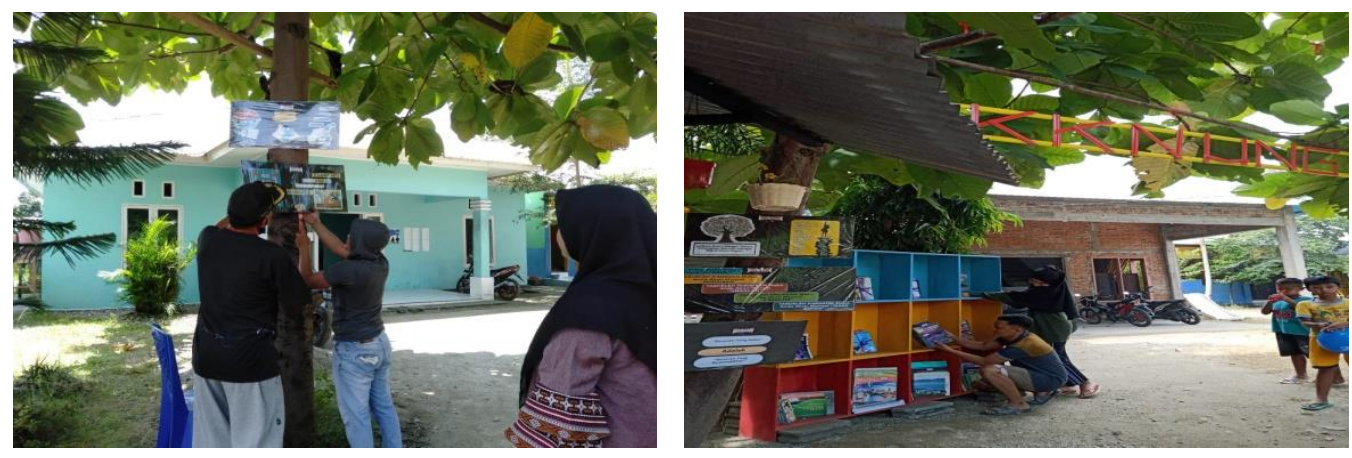

6. Pembuatan pondok literasi

Mahasiswa KKN-MBKM kemudian bekerja sama dengan aparatur dan masyarajkat desa pada proses pembuatan pondok literasi sebagai tempat baca masyarakat yang bersifat outdoor dalam peningkatan minat baca masyarakat. Pembuatan pondok literasi ini kemudian di tempatkan di desa Bubeya. 

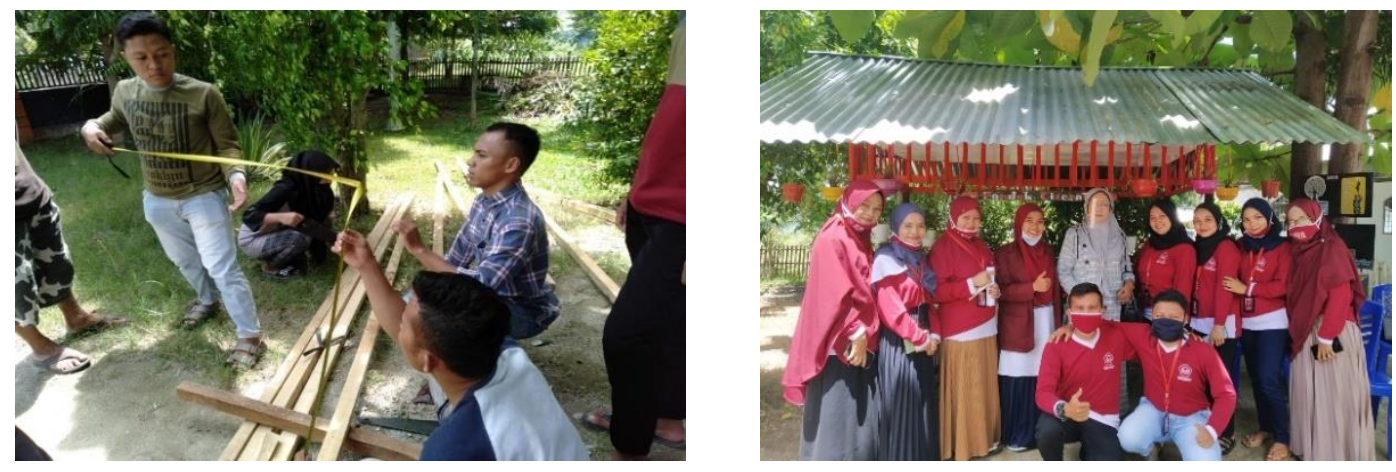

7. Pembangunan dan pengadaan taman literasi

Pembangunan dan pengadaan taman literasi selanjutnya mulai gencar dilaksanakan di desa Tinelo dan Boludawa. Mahasiswa melalui penggalangan donasi buku secara terbuka, membangun, mendekor taman baca dan membentuk struktur pegawai perpustakaan di taman baca tersebut bersama dengan masyarakat dan organisasi karang taruna setempat.
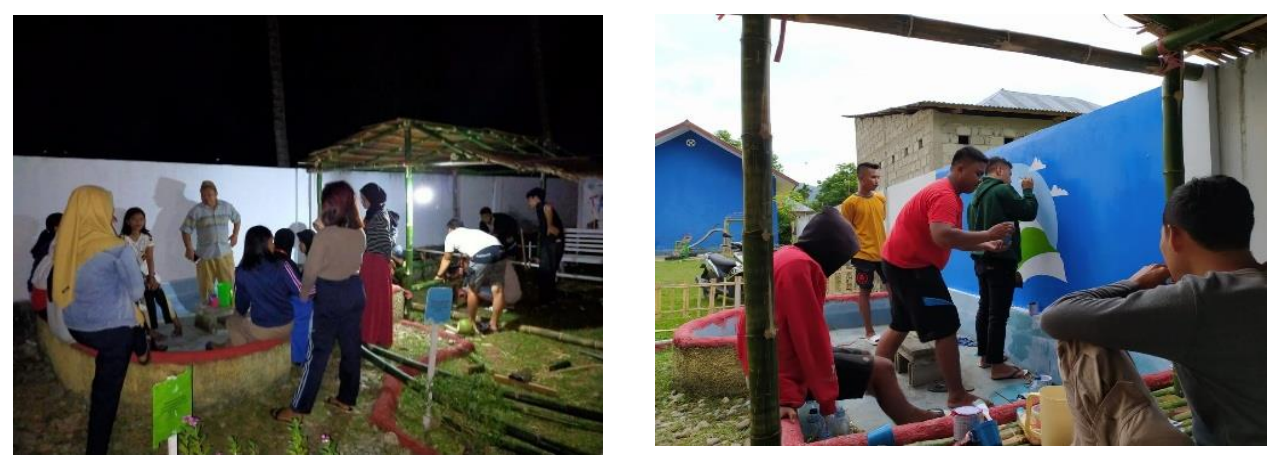

8. Pembentukan komunitas literasi

Pembentukan komunitas literasi kecamatan yang terdiri dari karang taruna desa Bubeya, Boludawa, dan Tinelo bekerja sama dengan komunitas sampul belakang dan sahabat pulau chapter gorontalo membentuk komunitas literasi yang meliputi perekrutan, diskusi literasi, penentuan nama komunitas sekaligus pembahasan 
program kerja komunitas dan diakhirioleh peresmian komunitas literasi yang diberi nama Pena danKertas "PENTAS" yang terdiri atas 10 orang anggota komunitas.

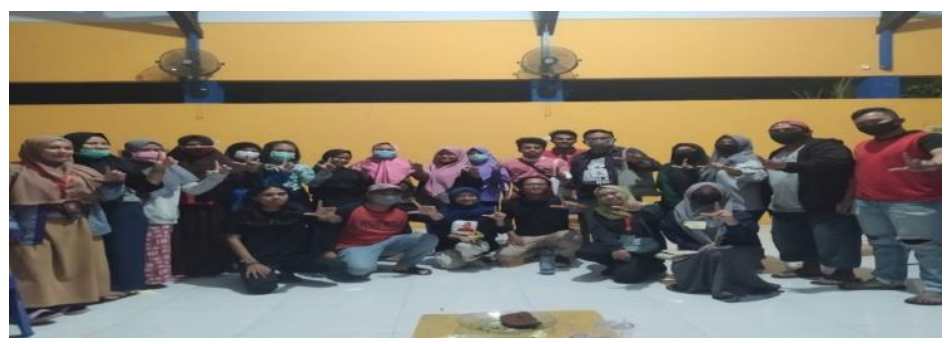

9. Sosialisasi pemberdayaan perpustakaan desa

Sosialisasi pemberdayaan perpustakaan desa dan peningkatan literasi masyarakat dirangkaikan dengan peresmian pondok dan taman literasi desa Bubeya, Boludawa, dan Tinelo. Kegiatan ini diharapkan mampu memberikan pemahaman luas kepada masyarakat desa akan pentingnya budaya literasi dan pelatihan masyarakat terkait pemberdayaan perpurstakaan desa sebagai acuan dalam membangun gerakan nasional gemar membaca.

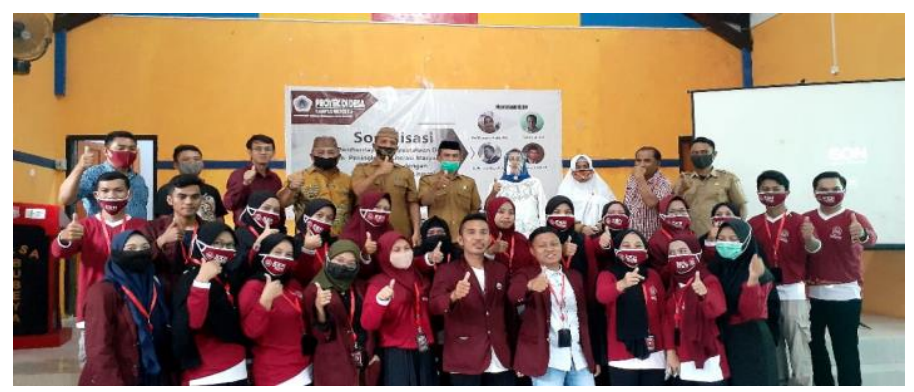

10. Peresmian perpustakaan, taman baca dan pondok literasi

Mahasiswa KKN beserta aparat desa dan karang taruna masingmasing desa Bubeya, Boludawa, dan Tinelo melaksanakan kegiatan peresmian taman baca desa Tinelo, perpustakaan baru desa Boludawa dan pondok literasi desa Bubeya yang diresmikan langsung oleh 
pemerintah kecamatan suwawadan dinas perpustakaan bone bolango. Kegiatan ini pun sebagai tahap awal agar diimpelementasikannya lapak-lapak baca serta gerakan gemar membaca pada desa Bubeya, Boludawa, dan Tinelo.

11. Pendampingan dan pemberdayaan taman baca, pondok literasi, dan perpustakaan

Pendampingan masyarakat sebagai usaha pemberdayaan taman baca, pondok literasi, dan peprustakaan dalam peningkatan motivasi awal literasi masyarakat, hal ini ditandai dengan dibukanya kegiatan rutin membaca setiap sore di pondok literasi, taman baca, serta mempergnakan peprustakaan desa, mahasiswa mengajak anakanak untuk membaca dongeng dan buku-buku yang telah disediakan lainnya sebagai tindak lanjut upaya peningkatan literasi baik bagi anakanak, remaja, dan dewasa.
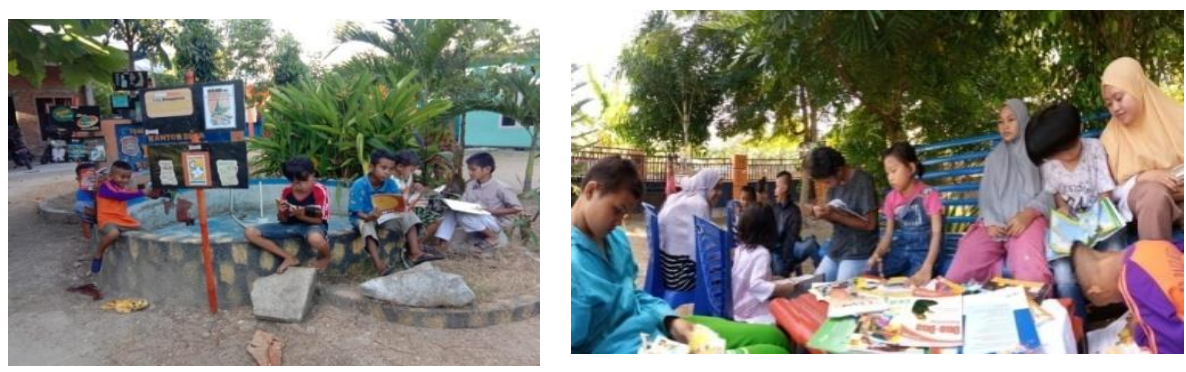

\section{Pembahasan}


Permasalahan minat baca menjadi hal yang sangat penting untuk dibahas. Masalah ini seharusnya bukan hanya menjadi perhatian satu pihak saja melainkan seluruh unsur masyarakat harus bersinergi untuk bisa mewujudkan generasi yang gemilang melalui kegiatan membaca. Terutama mahasiswa yang menjadi agen of change tentunya harus andil dalam mengalakkan program literasi. Hal ini yang kemudian menjadi fokus permasalahan yang oleh mahasiswa KKN UNG 2020 di Kecamatan Suwawa Kabupaten Bonebolango. Untuk bisa mensukseskan program gemar membaca yang sudah dicanangkan oleh pemerintah secara menyeluruh maka program literasi membaca ini harus dibangun dari unsur wilayah terkecil yaitu di desa.

Bicara memajukan literasi tingkat desa, bagi kami sudah selayaknya dilakukan. Tujuannya, agar pedesaan tidak selamanya berkonotasi dengan ketertinggalan dan keterbelakangan. Melainkan pedesaan yang cakap dalam kehidupan karena memiliki pemahaman literasi yang baik. Terlebih, mengingat kondisi minat baca yang ada di Gorontalo khsususnya di Kabupaten Bonebolango sangat rendah maka ini yang menjadi perhatian khusus dari program inti KKN UNG 2020 di Kecamatan Suwawa. Keterwujudan literasi ini tidak boleh parsial, perlu dilanjutkan tindakanya secara masif, guna mengedukasi masyarakat pedesaan menjadi bagian dari partisipan yang cerdas dan dewasa ikut menopang proses pembangunan daerah.

Tentang literasi sendiri (baca: paduan GLN, 2017:4), bukan hanya sekedar ngomong melek membaca, tetapi juga disimpulkan sebagai kemampuan memanfaatkan hasil bacaan tersebut untuk kecakapan hidup pembacanya. Jika substansi makna literasi demikian, kecakapan hidup yang baik itu cocok bila diprioritaskan di pedesaan. 
Dasarnya adalah, agar orang pedesaan mampu membangun kebangkitan diri, baik secara nalar dan sisi perekonomian, melalui pemahaman yang baik -positif- berbagai informasi kekinian, bisa diakses dari internet. Jika demikian adanya, literasi dalam konteks baca-tulis lagi-lagi menjadi salah satu kebutuhan yang harus dipenuhi dan tidak dapat dipisahkan dari kehidupan sehari-hari.

Salah satu upaya nyata dari mahasiswa melalui program KKN demi meningkatkan minat literasi generasi enerus bangsa setiap harinya perpustakaan desa di buka untuk umum agar siapapun dapat berkunjung dan membaca buku yang telah disediakan. Adapun program literasi yang dilakukan oleh mahasiswa sebagai pemecahan masalah minat baca di desa antara lain memberikan pengetahuan, pemahaman, pembiasaan, dan pelatihan perilaku. Program tersebut dapat diuraikan sebagai berikut:

(1) Pemanfaatan lingkungan yaitu dibangunnya taman baca, pondok literasi, dan gubuk baca yang masing-masing terletak di tiga desa yang menjadi lokasi pengabdian mahasiswa KKN UNG. Pemanfaatan lingkungan ini dilakukan agar bisa menumbuhkan minat baca dengan kondisi yang nyaman, menarik, dan mengasikan. Lingkungan yang asri dan indah seperti taman baca diharapkan mampu menarik perhatian baik dari pemuda dan anakanak sekitar.

(2) Pembuatan slogan mengenai pentingnya membaca yang diletakkan di area sekitar tempat bermain anak-anak dan berkumpulnya wargawarga desa. hal ini juga dilakukan sebagai upaya menambah wawasan dan menarik perhatian warga. 
(3) Sosialisasi pemberdayaan perpustakaan desa, kegiatan sosialisasi ini dilakukan untuk memberikan pengetahuan dan pemahaman mengenai pengelolaan perpustakaan desa. hal ini jjuga sebagai pemberdayaan pengelola perpustakaan yang telah dibentuk dari unsur karang taruna dan aparat desa di masing-masing desa lokasi KKN.

(4) Pembentukan komunitas literasi yang terdiri dari pemuda di desa. Masing-masing desa mengutus lima orang yang menjadi komunitas literasi di lingkungan kecamatan Suwawa. Hal ini dilakukan agar program literasi ini akan terus berkelanjutan sepeninggal mahasiswa di desa. Komunitas ini dibentuk oleh mahasiswa yang kemudian bekerja sama dengan komunitas literasi yang ada di sekitar wilayah Gorontalo.

Peresmian pondok literasi, taman baca, dan gubuk baca yang baru diadakan cukup menarik perhatian masyarakat, keterlibatan puluhan anak yang membaca dengan asiknya turut meramaikan budaya literasi. Hal ini sebagai apresiasi dari program inti yang dilaksanakan. Program ini diharapkan dapat terus dikembangkan guna membangun kesadaran pentingnya budaya literasi yang berkelanjutan bagi masyarakat. Sehingga ini juga menjadi bagian dari program pemerintah yaitu gerakan gemar membaca.

Ketersediaan perpustakaan kiranya perlu direalisasikan setiap desa. Tujuannya dalam rangka menggerakkan tradisi membaca melalui hadirnya "perpustakaa desa" yang dibentuk dan diciptakan berbasis desa. Tidak lain, agar keberadaan dan tidak sepenuhnya dialokasikan ke sektor fisik saja, melainkan juga perlu dipikirkan pada ketersediaan sarana baca berbasis masyarakat, sebagai media pembinaan sumber 
daya manusia (SDM), yang berdikari secara ekonomi dan memperkuat pengembangan karakter berkebangsaan berbasis lokal.

\section{KESIMPULAN}

Berdasarkan permasalahan yang telah dipaparkan di atas, staf pengajar Universitas Negeri Gorontalo mencoba memberikan kontribusi melalui keterlibatan mahasiswa dari Jurusan Bahasa dan Sastra Indonesia, untuk memberdayakan perpustakaan desa dan meningkatkan literasi masyarakat dalam program KKN Merdeka Belajar-Kampus Merdeka. Sebanyak 30 orang mahasiswa, diharapkan dapat mendampingi masyarakat Desa Tinelo, Bubeya, dan Boludawa di Kecamatan Suwawa selama 45 hari untuk mengoptimalkan tujuan dari program yang dimaksud.

\section{UCAPAN TERIMA KASIH}

Sehubungan dengan terlaksananya semua rangkaian program KKS Pengabdian, maka kami mengucapkan terima kasih kepada seluruh pihak yang telah terlibat pada pengabdian ini

\section{REFERENSI}

Oka, I Gusti Ngurah. 1983. Pengantar Membaca dan Pemahamannya.

Surabaya: Usaha Nasional

Rahim, Farida. 2008. Pengajaran Membaca di Sekolah Dasar.Jakarta:

PT Bumi Aksara.

Robandi, Imam.2010. The Ethos of Sakura: Bacaan Stratgeik PribadiSukses. Yogyakarta: PenerbitANDI. 
Samsuri. 1995. "Membaca dan Menulis Pilar Pembangunan Bangsa" dalam IQRO. Jember: UMJ Press. - 2016.Membangun Budaya Membaca di Sekolah Dasar Berbasis Revolusi Mental. Jurnal Volume 1, No. 2, September 2016.

Masyarakat Di Perguruan Tinggi Edisi IX, Direktorat Penelitian Dan Pengabdian Kepada Masyarakat, Direktorat Jenderal Pendidikan Tinggi Kementerian Pendidikan dan Kebudayaan, Tahun 2018.

Term of Reference (TOR) KKN Proyek di Desa "Kampus Merdeka". Universitas Negeri Gorontalo Tahun 2019. http://lpm.ung.ac.id 